\title{
Correction to: Pynchon and Philosophy
}

\section{Correction to:}

Martin Paul Eve, Pynchon and Philosophy, https://doi.org/10.1007/978-1-137-40550-0

The original version of the book was published in 2014 with exclusive rights reserved by the Publisher. As of October 2021 it has been changed to an open access publication: () The Editor(s) (if applicable) and The Author(s) 2021. All chapters in the book are licensed under the terms of the Creative Commons Attribution 4.0 International License.

Any third party material is under the same Creative Commons license as the book unless specified otherwise below. 